\title{
De Lípsio a Espinosa. Do horizonte da guerra à paz
}

\author{
Jacqueline Lagrée
}

Universidade de Rennes- 1

Tradução: Tessa de Moura Lacerda 



\section{Introdução}

Por que trabalhar este tema, a guerra e a paz, que pode parecer distante do proposto para este colóquio, sobre Republicanismo e democracia? Porque muitas coisas foram escritas, inteiramente pertinentes, sobre Espinosa, poeta da democracia, herdeiro do republicanismo de Maquiavel. Daí o desejo de considerar o problema a partir de uma outra perspectiva: sobre qual modelo se apoia a reflexão política na época clássica? A cidade grega? O império romano? A teocracia hebraica? As repúblicas italianas? A federação das Províncias unidas? Por que privilegiar um e não outro? Quais as consequências e apostas?

A reflexão política do século XVII não parte de um nada, e suas origens não se restringem apenas a Maquiavel e Tácito, explicam-se também por diferenças em relação a uma corrente extremamente forte no final do século XVI e no início do XVII: o neoestoicismo. Essa corrente é conhecida sobretudo por sua reabilitação da moral do Pórtico, mas a condensação de reflexões antigas sobre política em Justo Lípsio teve influência não apenas na vida política holandesa (com a defesa do princípio "uma só religião de Estado" ${ }_{1}$ ) mas também sobre Maurício de Nassau e a reorganização do exército holandês ou, mais tarde, sobre a organização do Estado prussiano. Ora, qual é o horizonte segundo o qual se desenvolve a política segundo Lípsio, que dedica a ela dois livros, Politica (1589), logo traduzido para o francês, e Monita et exempla politica (1595)? Esse horizonte é o da guerra, civil e religiosa, que então aflige a Europa há muitos anos. Ora, pensar a política tendo a guerra como horizonte leva Lípsio a privilegiar a monarquia e o modelo de um Estado forte e centralizado, segundo o exemplo do império romano de Augusto, pois a questão política por excelência é pensar a unidade de comando de uma multidão heterogênea sempre próxima da dissensão, da dissolução

1 Cujus regio ejus religio. 
e do caos. Compreender isso permite apreender melhor como, em contrapartida, o modelo democrático evocado por Espinosa é construído tendo a paz em perspectiva.

\section{O neoestoicismo: o horizonte da guerra exige a monarquia}

O ressurgimento do neoestoicismo no final do século XVI e início do XVII está claramente ligado ao fato de se tratar de uma época difícil. A Europa como um todo conhece nesse momento um período de instabilidade e de guerras civis e religiosas, que Lípsio atribui a duas causas principais, uma teológica, outra moral, as "chamas de dissensão, acesas pela religião" (Lípsio, 1590, IV, 3) e a falta de virtude dos príncipes degenerados (Cf. Lípsio, 1584, II, 20). A luta de Flandres contra a monarquia espanhola, os combates intelectuais e militares entre religiões dominantes e dominadas ${ }^{2}$, o receio em relação à multidão, os novos dados econômicos e políticos ligados à extensão do comércio ao Novo Mundo, tudo isso impõe uma reflexão política que versa menos os fundamentos do Estado (contrato social ou sociabilidade natural) do que a sua organização, o funcionamento do governo e a atitude a ser adotada face à guerra, quer se trate do Príncipe ou do súdito.

A Politica e seu prolongamento, a Monita et exempla politica, não se dirigem ao povo, que não tem direito de voz, mas ao Príncipe e a seus conselheiros. Pois é do Príncipe e de seus vassalos que vem a guerra; não se pensa aqui na possibilidade de levante popular ou de revoluções, mas no risco de facções sediciosas comandadas pelos príncipes ou pelas elites, seguidas por descontentes.

Que guerras devem ser temidas? Antes de tudo a guerra externa ${ }^{3}$, de defesa, de conquista ou de liberação de uma potência estrangeira, como foi o caso em Flandres contra a potência es-

\footnotetext{
2 Que suscitam o princípio cujus regio, ejus religio.

3 "vim et arma in principem aut populum alienum [uma força e armas no encontro de um Príncipe e uma população estrangeira]” (Lípsio, 1590, V, 3).
} 
panhola. Mas a guerra pode ser também interna ou civil, com o desenvolvimento de facções que muitas vezes se apoiam em pretextos religiosos. A guerra civil é a mais temível: "Sabei que uma grande cidade ou um estado não pode ficar por muito tempo em repouso; se ela não tem inimigos externos, os encontrará em si mesma. É preciso restringir e coagir essa peste interna e doméstica, e turbar os outros, antes de vos perderes" (Lípsio, 1590, p. 45).

A guerra nada mais faz que levar ao extremo problemas e soluções que são também problemas e soluções do Estado em tempos de paz. Lípsio, de maneira muito realista, enumera, entre os instrumentos do governo, cinco principais, que intervêm todos, igualmente, na guerra: o dinheiro, as armas, os conselhos, as alianças e a fortuna4 (Cf. Ibid., IV, 9). Notar-se-á que as armas vêm antes dos conselhos. O dinheiro é o nervo do império para obter mercenários e aliados. Depois vêm as armas, "pois é certo que os grandes impérios não se dedicam à ociosidade e à preguiça, mas ao combate com homens e armas" (Ibid.). Em seguida os conselhos de prudência e moderação, pois é mais fácil tomar uma província do que mantê-la; sem esquecer os aliados potentes sem os quais não se poderia perdurar. Por fim, a fortuna, embora seja uma ajuda frágil, e por definição aleatória. Armas, aliados e fortuna são instrumentos mais requeridos na guerra que na paz, o que mostra bem que a guerra é o horizonte da vida civil.

Quem declara, conduz ou põe fim à guerra? Somente o príncipe; e é exatamente a ameaça de guerra que faz Lípsio preferir o modelo monárquico ao modelo republicano. Lípsio exclui (como Espinosa) as mulheres do governo porque "a mulher carece de força, de constância e de prudência para governar” (Ibid., II, 3, p. 24a). Ainda mais na guerra que na paz, o corpo político deve "ser conduzido por um único espírito, assim como o navio é condu-

4 Opes, arma, consilia, foedera, fortuna. 
zido pelo piloto"5 (Ibid., II, 2, p. 22b). O chefe militar será, nesse sentido, a alma do exército e o modelo do Príncipe civil. A preferência pela monarquia está estreitamente ligada à exigência de unidade de comando. O problema político não é "como fundar um Estado?", mas sim, “como estabelecer a unidade de uma multidão sempre suscetível de decomposição?” ${ }^{6}$ (Ibid.). Isso implica não apenas a unidade de comando, mas também a unidade de religião do Estado, pois diferenças religiosas são causas ou pretextos para conflitos civis e, portanto, um travo à tolerância.

O espelho do bom chefe militar7 serve também como espelho do bom governante ${ }^{8}$. É reconhecido por cinco marcas (Lípsio, 1590, V, 15): a competência9 (scientia), a virtude ${ }^{10}$ (virtus entendida como vigor e probidade), a precaução ${ }^{11}$ (providentia), a autoridade (auctoritas) e a fortuna ${ }^{12}$, ou boa sorte. Esse retrato do grande chefe militar servirá de modelo a Maurício de Nassau, que foi aluno de Lípsio e a quem este último dedica seu livro, quando publicado em 1589.

Não me interessam aqui as condições da guerra, o jus ad bellum et in bello, a diferença entre guerra justa e guerra injusta, o papel político e demográfico da guerra, tampouco a maneira de encerrá-la em bons termos ${ }^{13}$. Gostaria antes de insistir sobre dois pontos: como evitar a guerra civil que ameaça continuamente a unidade e a estabilidade do Estado? E quais são as virtudes do

5 E mais a frente "é pelo bem da paz que é necessário transferir toda a potência a um só".

6 O que já era a questão de Maquiavel no Príncipe.

7 O chefe é a alma do exército.

8 Em francês: "portrait" [retrato] remetendo-se aos textos que aconselhavam o governantes e são chamados "Portrait du Prince", traduzidos em português como "Espelho dos príncipes". [N. da T.]

9 Prática militar, estratégia e tática.

10 Vigor de corpo e de espírito; ser o primeiro na necessidade, em meio aos soldados; temperança e humanidade.

11 Antecipação sem impetuosidade.

12 Felicidade e boa fortuna; escolher de preferência chefes com quem deu tudo certo. A fortuna desempenha um papel maior na guerra que na paz.

13 Ver meu artigo "Anthropologie et guerre au XVII siècle". In: Penser la guerre au XVII siècle, PU Paris 8, 2011. 
cidadão adquiridas na prática militar?

\section{Como evitar a guerra civil?}

Se guerras são sempre ruins, a pior guerra é a guerra civil, um "levante de armas dos súditos, movidos de encontro ao príncipe ou uns contra os outros." (Ibid., VI, 1, p. 234b). Aqueles que buscam a guerra civil saem de sua humanidade, ainda que a guerra seja um fenômeno propriamente humano. A guerra civil é a desordem absoluta; ela exclui toda disciplina e toda hierarquia entre capitão e soldados. Do outro lado do Rubicão, César e um simples soldado se tornam iguais, "César era meu general nas margens do Reno, aqui, somos companheiros." ${ }^{14}$ (Ibid., VI, 1, p. 236a).

Existem signos premonitórios da perturbação do Estado: ondas de acusação, de adulação, de insolência, desordens. O Príncipe não deve buscar a guerra civil, mas, ao contrário, fazer de tudo para evitá-la. Esta tem dois tipos de causas, as próximas, que são visíveis, e as remotas, desconhecidas, ainda mais importantes do que as primeiras. As causas remotas são o destino - codinome a providência, pois é pelo interior que Deus destrói os maiores impérios - e o luxo. Um Estado é como um organismo: tem um talhe ideal e uma duração de vida limitada. O luxo, ou excesso de riqueza, enfraquece os costumes e perturba a república. Não se pode nada contra o destino e a lei de mutação universal das coisas do mundo, mas pode-se impedir o luxo, através da censura.

As causas próximas da guerra são três: facções, sedição, tirania (Ibid., VI, 3). Facções são "uniões de alguns em desacordo com os outros" (Ibid.). Lípsio lhes dá como origem a ambição de ser o primeiro, mais do que o interesse. São mais próprias da nobreza que do povo. E devem ser reprimidas na origem, como diz Aristóteles (Aristóteles, Política, 1303b 26). A segunda causa próxima é a sedição, "um sentimento súbito e violento da multidão contra

14 Citação de Lucain. 
o príncipe ou os magistrados" (Lípsio, 1590, VI, 4, p. 242b). A sedição é gerada pelo temor (Aristóteles, 1302b 21), pela insubordinação ou pela pobreza. Com muito mais frequência, porém, é provocada pelos poderosos, que se servem do contágio dos afetos da multidão para abalar o Estado e atingir mais rapidamente os seus objetivos. A sedição, com o pretexto da liberdade, é a porta aberta para a tirania. "Para derrubar o Estado eles escondem a liberdade, depois, quando ele é inteiramente destruído, é a ela que eles desejam” (Lípsio, 1590, p. 244b). Aí também é preciso intervir na hora certa, pois "todo mal que acabou de nascer é facilmente sufocado; aquele que já envelheceu é ordinariamente mais forte e mais impiedoso" (Ibid., p. 245b). O rei se serve das armas para garantir a paz, o tirano para o ódio e o temor e "quando eles desertaram [tornaram deserto] seu Estado, eles querem que seja paz" ${ }^{15}$ (Ibid.). E, todavia, Lípsio não recomenda o tiranicídio, mas antes, que se suporte o tirano como se faz nas catástrofes naturais, pois "a guerra civil é pior e mais infeliz que a tirania."

\section{As virtudes da guerra}

Se a guerra é um resumo da vida política, ela exige e desenvolve virtudes específicas que se mostram igualmente utilíssimas em tempos de paz. Elas diferem conforme se trate do Príncipe ou dos súditos.

O Príncipe deve dar mostras de coragem, não de temeridade. Deve também desenvolver a prudência militar, "que intervém na guerra quando as coisas estão conturbadas e há dissensão” (Ibid., $\mathrm{IV}, 2$ ). A prudência é a qualidade que compreende e escolhe o que nas coisas públicas deve ser buscado ou evitado (Ibid., I, 7). É uma virtude tão essencial ao príncipe quanto o olho é para o ci-

15 Fórmula tomada de empréstimo a Tácito (Agricola XXX, 6) e que encontra eco na famosa observação de Espinosa: "aquela cidade cuja paz depende da inércia dos súditos, os quais são conduzidos como ovelhas, para que aprendam só a servir, mas corretamente se pode dizer uma solidão do que uma cidade.” (Espinosa, 2009, p. 45). [N. da T.] 
clope $^{16}$ ou a bússola é para o piloto do navio. O Príncipe também precisa ter experiência, adquirida pelo estudo da história, uma vez que sua experiência pessoal se limita a alguns anos e a uma região do globo, enquanto a história se estende por séculos e por toda a terra. Daí a importância de uma formação baseada na cultura latina, marcada pelo feitio marcial.

É impossível para o cidadão escapar à guerra: ela está em toda parte. É preciso, portanto, preparar-se para ela.

Há muitos anos que somos presas da agitação das guerras civis, que somos sacudidos por todos os ventos, como num mar tempestuoso, por perturbações e sedições. Se busco o repouso e a calma do coração, sou ensurdecido pelo som das cornetas e o estrondo das armas; se me refugio nos jardins, soldados e sicários devolvem-me para a cidade (Id., 1873, I, 1, p. 133).

A disciplina é, com a ordem, a virtude por excelência do soldado (ver Lípsio, 1590, V). É ela que está na origem do Império Romano (ver Ibid., V, 13). Lípsio a define como "um severo comando do homem de guerra, conforme sua força e virtude" (Ibid., 19ob). É adquirida por treinamento (exercícios ${ }^{17}$, ordem, castigos e exemplos); opõe-se à insubordinação, e está ligada à cultura, que permite o domínio de si, e ao valor do trabalho. Uma multidão indisciplinada é um obstáculo e um fardo para a guerra (Cf. Ibid., V, 8). A disciplina é ao mesmo tempo formação e treinamento, exercício, e pode-se considerar que o que vale para o soldado vale também para o cidadão, uma vez que ela "mantém e conserva o Estado e a república" (Ibid.).

Não esperai que uma vitória ou a boa fortuna caia do céu, no colo daquele que é preguiçoso e ocioso. A paga pelos bens que 
recebemos de Deus é o trabalho. Nossos semelhantes trarão misérias e calamidades, mas Deus haverá de detê-los, vós me direis. Mas ele não descerá do céu por vós, dar-vos-á entendimento, para que vos desvies deles e detenha-vos a si mesmo (Ibid., I, 4).

A obediência deve ser imediata e sem questionamento: "as coisas da guerra correm melhor obedecendo-se e se fazendo o que é ordenado, e não buscando-se e se inquirindo a razão pela qual os comandos foram dados" (Ibid., V, 13, p. 197b).

\section{A organização militar é modelo da organização política}

O neoestoicismo é conservador em política. Insiste sobre a necessidade, para o Príncipe, de conhecer bem seu Estado, de medir suas forças, de se ocupar com a disciplina militar, modelo de disciplina civil, como no império romano. A ética do Pórtico irriga esse elogio da disciplina. Ela não visa somente a obediência e a força do soldado, mas também sua virtude, uma vez que esta é definida como um "processo severo, para tornar o soldado mais valente, e homem de bem”. Essa disciplina não é somente obediência às ordens, mas autodisciplina, hábito de suportar o frio, a fome, a fadiga. Caso se acrescente que o exército profissional é um órgão permanente do governo político, vê-se melhor como ele constitui um modelo de controle de um Estado centralizado e unificado por uma unidade de comando. O neoestoicismo assegura assim a passagem das virtudes militares, tradicionalmente aristocráticas (coragem heroica, por exemplo), para as virtudes burguesas (ordem e método, simplicidade, valor do trabalho e do treinamento cotidiano). As medidas apresentadas com as citações dos Antigos nos Políticos e ilustradas por exemplos modernos nos Conselhos, a unidade de comando, o pequeno número de leis ${ }^{18}$,

18 "As leis, numa república, devem ser como os remédios. Ora, eles não devem ser abundantes e diversificados para serem bons, tampouco elas. O grande número de leis não faz bons costumes nem o bom direito, mais do que um pequeno número bem ob- 
a unidade de religião, visam, todas, a conservar melhor a unidade do Estado, sempre ameaçado, tanto do interior como do exterior, pela versatilidade conjunta da multidão e da fortuna. Compreende-se, pois, que G. Ostereich tenha escrito sobre isso que "a força militar é o verdadeiro fundamento do Estado moderno."

Assim, a guerra, no neoestoicismo, é ao mesmo tempo um conceito, um paradigma e uma metáfora: o neoestoicismo constrói um conceito de guerra, entendido como subespécie do combate animal por território, com suas características próprias, que são a preparação, a conduta metódica e o fim pacífico. Daí a distinção entre as guerras justas e as injustas, não pertinente no caso do combate animal, que não chega jamais à forma global e total da guerra.

A guerra, além disso, é um paradigma do governo do Estado, que se dá sempre no horizonte do conflito e da ameaça de guerra civil e exige preparação, instrumentos, método e virtudes particulares. As virtudes do bom chefe militar são eminentemente as do bom príncipe.

A guerra, por sua violência, pela impossibilidade de um controle total, pela importância do acaso, é, por fim, uma metáfora das turbulências climáticas (a guerra dos elementos no De constantia) e das reviravoltas da fortuna e, portanto, da fragilidade do homem face à natureza e à história.

A reflexão sobre a guerra tem, assim, implicações não somente políticas, mas quase que metafísicas e morais. A primeira é o primado da ordem, pois a guerra, mesmo quando metodicamente conduzida, é fonte e efeito de desordens. A segunda é que a guerra é sempre detestável, mesmo quando é justa ${ }^{19}$.

Enfim, notar-se-á que, apesar de suas implicações políticas

servado" Monita et exempla politica (1595?), II, 10. Lípsio critica o direito justiniano, muito abundante e, no entanto incompleto.

19 Ela deve ser "abominada pelo príncipe devoto e cristão que, segundo a divina lei, deve ser tão parcimonioso com o sangue de outro quanto é com o seu próprio” (Lípsio, 1590, V, 5, p. 167b). A divina lei é a regra de ouro. 
e do papel desempenhado por essa filosofia na reorganização do exército ou na concepção prussiana de Estado, o neoestoicismo tem uma concepção mais moral que política ou estratégica da guerra. Recorde-se a insistência nas virtudes militares (continência, modéstia, abstinência). A ausência dessas virtudes destrói a mais inteligente das estratégias, como mostra o exemplo de Aníbal: "ele venceu com as armas, mas foi vencido pelos vícios" (Lípsio, 1590, V, 13, p. 195a).

\section{A inversão espinosana}

Mesmo sem ter escrito muito sobre a democracia (comparativamente ao número de páginas dedicadas à monarquia ou à teocracia hebraica), Espinosa é geralmente considerado - a justo título - um pensador republicano ou democrata. Sem julgar aqui a pertinência de qualificativos cujo sentido mudou bastante nos últimos três séculos, gostaria de sublinhar a inversão operada por Espinosa face ao modelo neoestoico apresentado acima. Mostrarei isso a partir de várias perspectivas possíveis:

Em primeiro lugar, e principalmente, a mudança de sentido e de valor do conceito de multitude entendida como potência ativa ou como causa eficiente e não mais como perigo potencial de desordem ${ }^{20}$.

Uma análise dos afetos separada de uma análise moral das virtudes e dos vícios, que determina afetos pró e antipolíticos, e uma geometria dos afetos que permite fazê-los funcionar no sentido do interesse comum. Vê-se, por exemplo, o caso da prudência misturada ou a arte de "unir a raposa e o leão".

A mudança de orientação da análise da origem para a perspectiva que mostra o liame entre a paz, a prosperidade e a liberdade de consciência em lugar do liame inicial entre guerra, contrato social, obediência e segurança. 
A exigência da democracia real e da tolerância ativa no seio de todas as formas de governo.

Seria lícito aplicar a Espinosa o modelo de republicanismo elaborado por Philip Pettit em seu livro homônimo de 1997, embora Pettit quase não cite Espinosa? Lembremos as principais de suas teses principais que poderiam nos ser úteis aqui:

A finalidade do Estado é a promoção da liberdade como não dominação (Espinosa, 2005, p. 11), o que corresponde às teses do capítulo XX do Tratado teológico-político.

Essa liberdade é menos definida como dominação de outro ou domínio de si (Cf. Pettit, 1997, pp. 31-47) do que como não interferência, isto é, em linguagem espinosana, liberdade de trocas.

O Estado deve assegurar a segurança dentro do quadro da lei (Ibid., pp. 48-57).

\section{A multidão e seus afetos}

Para compreender a inversão de perspectiva operada por Espinosa, é preciso retomar seu vocabulário político e compreender a distinção de sentido e valor dos termos empregados para designar a fula ou o povo. Examinemo-los:

Multitudo, a multidão, designa a massa enquanto governada por afetos e constitui antes de tudo uma potência; a questão essencial não é o risco de sua dissolução, mas sua atividade e seus efeitos e a maneira de fazê-la agir veluti uma mente, como uma só mente ou um só coração.

Vulgus, a fula, designa a multidão sob o aspecto de sua passionalidade; para retomar as palavras de Tácito, "a fula é terrível quando não teme" (Tácito, Anais, I, 29) ${ }^{21}$. Embora seja ávida por novidade, sujeita a superstição, sempre agitada e causa de guerra (Espinosa, 1999, p. 61), ela é também inventora da linguagem ordinária e comum. Esse termo é o que corresponde mais à descri- 
ção depreciativa da fula em Tácito e Lípsio.

Populus, o povo, designa uma multidão unificada por uma constituição e uma história comuns: o povo romano, o povo hebreu sob a lei mosaica. Não há povo sem Estado.

Plebs, a plebe, marca a parte ignorante, até atrasada do povo, mas majoritária, levada pela opinião, propensa à sedição. À plebe opõem-se os patrícios.

Gens ou gentes designa a nação, que é uma criação histórica, pois a natureza não cria nações, somente indivíduos; sua duração de vida é necessariamente finita.

O que está em jogo no republicanismo de Espinosa é o estatuto da multidão. A multidão é guiada por seus afetos e não pela razão ${ }^{22}$, mas de maneira ambivalente: ela suscita o temor quando ela mesma teme e seu medo está sempre misturado com esperança: "aqueles que se persuadem de poder induzir, quer a multidão, quer os que se confrontam nos assuntos públicos, a viver unicamente segundo o que a razão prescreve, sonham com o século dourado dos poetas, ou seja, com uma fábula” (Id., 2009, p. 9).

Daí que a tarefa da política seja dirigir a multidão de tal maneira que, crendo obedecer a seus afetos, ela se aproxime, todavia, da razão, ou pelo menos tenda a isso. É utópico esperar que a multidão escape à ambivalência afetiva e à fluctuatio animi, mas pelo menos uma legislação adequada pode anular os efeitos de dissolução dessa inconstância afetiva.

Dado que os homens, como dissemos, se conduzem mais pelo afeto que pela razão, segue-se que não é por condução da razão, mas por algum afeto comum que uma multidão se põe naturalmente de acordo e quer ser conduzida como que por uma só mente (...), ou seja, por uma esperança ou medo comuns, ou pelo desejo de vingar algum dano comum. Como

22 "aqueles que sabem a que ponto a compleição da multidão é diversa, quase se desesperam pois ela se governa não pela razão, mas somente pelos afetos” (Espinosa, 1999, P. 541). 
porém o medo da solidão existe em todos os homens, porque ninguém na solidão tem forças para poder defender-se e reunir o necessário para a vida, segue-se que os homens desejam por natureza o estado civil, não podendo acontecer que eles alguma vez o dissolvam por completo (Ibid., p. 47).

Entregue a si mesma, a multidão não será um corpo, mas um agregado sem ordem (Id., 1999, p. 212)²3; é preciso, pois, dar-lhe uma mente, conduzi-la veluti uma mente, por afetos que se dirijam para o bem comum. Com efeito, se uma parte desses afetos constitui um núcleo antipolítico, esses mesmos afetos podem ser reorientados para uma boa organização legislativa e institucional que vise a estabilidade e a paz do Estado. Foi isso que soube fazer particularmente bem a teocracia hebraica, que, embora não seja, à primeira vista, um modelo de democracia, é, em outro sentido, eminentemente democrática, uma vez que, obedecendo-se a Deus, é-se liberado da obediência do homem. Como se sabe, para Espinosa, a fraqueza intrínseca da teocracia hebraica, o verme que comeu o fruto por dentro, é o estatuto privilegiado dos Levitas.

Espinosa coloca assim, lado a lado (ver Espinosa, 2009, I, 1 e 2), os filósofos que deploram as paixões humanas e não podem conceber uma política aplicável concretamente, e os políticos, "mais hábeis que sábios", que colam tanto na experiência que se esquecem das exigências éticas. Um conhecimento mais apurado da natureza humana e do jogo dos afetos mostra que há no homem, ao mesmo tempo, um núcleo resistente de paixões antipolíticas e uma demanda afetiva e racional por organização política. O núcleo de paixões antipolíticas (ver Id., 1999, pp. 407-465) é constituído pelo sistema de inveja, cólera, ódio, desejo de dominar o outro, a preguiça, a avareza, o desejo de glória ou de luxo,

23 coetus inordinatae multitudinis. 
o apetite por novidade que suscita quedas de regimes, a má-fé e o desrespeito pelas promessas, que fazem de cada homem um inimigo potencial do Estado. Todo esse conjunto engendra rivalidades, discórdias, e tende finalmente à destruição do Estado. Mas há conjuntamente um feixe de afetos favoráveis à organização de uma sociedade estável e bem regulada, como o desejo de segurança e de paz, a aspiração por uma vida melhor, a necessidade de ajuda mútua, a aspiração à razão, o desejo de conhecer e compreender. Tudo isso produz uma aspiração passional por benefícios da razão que compreende, ao mesmo tempo, o desejo de sair dos afetos das discórdias e do ódio e o desejo de gozar do bem-estar da cultura. Esse conjunto suscita a demanda de associação, o sentido de solidariedade inter-humana e contribui para a construção e a perpetuação da sociedade.

O Estado não é, pois, fundado sobre as exigências da razão, embora corresponda a isso, mas sobre a natureza passional dos homens; não depende das virtudes ou dos vícios dos dirigentes (Tomás de Aquino ou Lípsio contra Maquiavel), mas de um sistema de regulação interna que leva em conta as paixões, as potências e as aspirações à razão.

\section{A guerra, a paz e a liberdade de pensar}

O problema essencial que a multidão coloca ao filósofo é a da possibilidade de sua unidade simultânea de pensamento e de ação, e a dificuldade de conduzi-la como por uma só alma, ut multitudo una veluti mente ducatur sicut in imperio requiritur, como é exigido pela vida civil comum²4. Essa questão não é mais encarada a partir de um estado de guerra inicial, mas em relação a uma exigência de paz que não é mais pensada como ausência de

\footnotetext{
24 "Todavia, porque a razão ensina a praticar a piedade e a ser de ânimo tranquilo e bom, o que não pode acontecer senão no estado; porque, além disso, não se pode fazer que a multidão seja conduzida como que uma só mente, conforme se requer no estado, a não ser que tenha direitos que sejam instituídos segundo o preceito da razão..." (Espinosa, 2009, p. 22).
} 
guerra, mas sim como "união ou concórdia de ânimos" (ver Espinosa, 1999, pp. 407-465), o que é a própria definição da unidade de espírito buscada e que faz da multidão uma potência eficiente. Daí a referência à paz, nos dois subtítulos dos dois tratados políticos de Espinosa ${ }^{25}$, com a pequena diferença que vai de "a paz e a piedade da república" para "a paz e a liberdade dos cidadãos", o que mostra bem que o fim não é somente uma finalidade, mas antes uma condição ou um constituinte da república, isto é, da união da multidão.

Sem a concórdia, isto é, sem a união de pensamento e de ação, não há vida política, só um deserto (Id., 2009, V, 4). Uma cidade na qual cidadãos não pegam em armas porque estão paralisados pelo medo não está em paz, está apenas sem guerra, porque a paz não é um estado negativo (a ausência de guerra), mas uma virtude positiva, uma força de alma que se traduz pela vontade de obedecer livremente à lei.

Deve, no entanto, notar-se que o estado que eu disse instituído para este fimm $^{26}$ é, no meu entender, aquele que a multidão livre institui, não aquele que se adquire sobre a multidão por direito de guerra. Porque a multidão livre conduz-se mais pela esperança que pelo medo, ao passo que uma multidão subjugada conduz-se mais pelo medo que pela esperança: aquela procura cultivar a vida, esta procura somente evitar a morte; aquela, sublinho, procura viver para si, esta é obrigada a ser do vencedor, e daí dizemos que esta é serva e aquela é livre. Assim, o fim do estado de que alguém se apodera por direito de guerra é dominar e ter servos em vez de súditos (Ibid., p. 45).

25 "Tratado teológico-político, contendo algumas dissertações em que se demonstra que a liberdade de filosofar não só é compatível com a preservação da piedade e da paz, como inclusive, não pode ser abolida sem se abolir ao mesmo tempo a paz do Estado e a própria piedade". "Tratado político onde se demonstra como deve ser instituída uma sociedade em que tem lugar um estado monárquico, assim como aquela em que imperam os melhores, para não resvalarem para a tirania e para manterem invioladas a paz e a liberdade dos cidadãos."

26 A paz e a segurança (Espinosa, 2009, V, 2) . 
$\mathrm{O}$ risco de guerra que mais ameaça o Estado, para Espinosa, não é a guerra exterior, mas a guerra civil. Todo poder corre o risco de voltar à multidão desunida, seja pela morte do rei (daí a importância de regras de sucessão), seja pela corrupção da assembleia. "A razão ensina absolutamente a procurar a paz" (Ibid., p. 28) e a paz é um bem cujo "preço (...) nunca é demasiado alto" (Ibid., p. 106). Ora, a busca da paz e da concórdia constitui também "o supremo exercício da caridade" (Ibid., p. 31), conforme ao direito do Estado, sem ser perturbado por cultos exteriores (Ibid.).

\section{A exigência de democracia em toda forma de governo}

Como a paz, que implica o consentimento dos Estados como dos indivíduos, é por excelência a virtude de um Estado democrático (ver Ibid., VII, 5), pode-se pensar que haveria em todo governo um momento ou uma exigência de democracia.

Como proteger seu Estado? Maquiavel mostrou bem os meios, mas não foi muito claro sobre o fim, que deve ser a paz e a segurança. Todavia, apesar de seu silêncio, Maquiavel foi sem dúvida aquele que melhor compreendeu a exigência de democracia.

Além disso, ele quis talvez mostrar quanto uma multidão livre deve precaver-se para não confiar absolutamente a sua salvação a um só, o qual, a não ser que seja vaidoso e julgue que pode agradar a todos, deve temer ciladas todos os dias, e por isso é obrigado antes a precaver-se a si mesmo e a armar ciladas à multidão do que a olhar por ela. E sou tanto mais levado a crer isto deste homem prudentíssimo quanto consta ele ter sido pela liberdade, para cuja defesa também deu conselhos muito salutares (Ibid., p. 46).

Para entender isso, é preciso retomar as definições de soberania e das formas de sua constituição. 


\section{Soberania}

O direito do Estado não é outro que a potência da multidão unificada ${ }^{27}$; o portador da soberania é, portanto, sempre a multidão; o soberano, monarca ou assembleia, é apenas o detentor do poder, por tanto tempo quanto a multidão o conceda, de acordo com um modelo que lembra a diferença introduzida por Hobbes no Leviatã entre o autor (o povo) e o ator (o príncipe). A democracia é, pois, o poder absoluto. Os atributos da soberania são o poder legislativo (Espinosa, 2009, IV, 2), o poder judiciário ${ }^{28}$, o jus circa sacra ou a regulação dos negócios religiosos e o direito de decidir sobre a guerra e a paz.

Esse direito que se define pela potência da multidão costuma chamar-se estado. E detém-no absolutamente quem, por consenso comum, tem a incumbência da república, ou seja, de estatuir, interpretar e abolir direitos, fortificar as urbes, decidir sobre a guerra e a paz, etc. E se esta incumbência pertencer a um conselho que é composto pela multidão comum, então o estado chama-se democracia; mas, se for composto só por alguns eleitos, chama-se aristocracia; e se, finalmente, a incumbência da república e, por conseguinte, o estado estiver nas mãos de um só, então chama-se monarquia (Id., 2005, p. 107).

\section{República}

O termo respublica, traduzido por república, aproxima-se muito de imperium, traduzido normalmente por Estado. O que faz a república ou a coisa comum é a organização da multidão segundo leis, que a fazem passar de massa a povo. Vê-se isso claramente no elogio a Amsterdã, no fim do prefácio do Tratado teológico-político. A lei suprema da república é o bem-estar do

27 "Do art. 15 do capítulo anterior resulta claro que o direito de estado, ou dos poderes soberanos, não é senão o próprio direito de natureza, o qual se determina pela potência, não já de cada um, mas da multidão, que é conduzida como que por uma só mente" (Espinosa, 2009, p. 25). Mesma formulação em (Ibid., III, 7).

28 "estatuir, interpretar e abolir direitos" (Ibid., p. 20). 
povo e não dos dirigentes.

Se o fim da ação é a utilidade não daquele que age, mas do que comanda, então o agente é escravo e inútil para si mesmo. Mas em uma república e um Estado [in republica et imperio] no qual a salvação de todo o povo e não a do chefe é a lei suprema ${ }^{29}$, aquele que obedece inteiramente ao poder soberano não deve ser chamado um escravo inútil, mas um súdito. A república mais livre é, pois, aquela cujas leis estão fundadas na sã razão, porque cada um, quando quer, pode ser livre, isto é, viver plenamente sob a conduta da razão (Id., 1999, p. 519).

A formação da república exige, portanto, que "toda a potência de decidir esteja nas mãos de todos ou de alguns ou de um só”, o que Espinosa demonstra em dois tempos: 1. "Cada um transfere inteiramente a potência que detém à sociedade, que conservará sozinha, pois, o direito soberano da natureza sobre todas as coisas, isto é, o poder soberano ao qual cada um deve obedecer, livremente ou por medo do último suplício" (Ibid., XVI, 8). 2. Esse modelo democrático é, em seguida, estendido a todos os tipos de Estado, "pois aquele que detém o poder soberano, quer se trate de um só homem, de um pequeno número ou, enfim, de todos, possui, isso é certo, o direito supremo de ordenar tudo o que quer" (Ibid., XVI, 11), e, nessa transferência de direito "cada um abandonou somente o direito de agir segundo seu próprio decreto, mas não o direito de raciocinar e de julgar" (Ibid., XX, 7).

Monarquia e aristocracia conservam, portanto, um elemento democrático, quando visam a paz, porém, com uma nuança; a monarquia visa preservar a paz e a concórdia (Id., 2009, VII, 8), enquanto a aristocracia quer preservar a paz e a liberdade (Ibid., VIII, 7). Ademais, a organização, em cada regime político, da relação numérica entre detentores do imperium e multitudo in-

29 "Salus populi suprema lex esto" (Cicéron, De Legibus, III, 3). 
troduz em cada um, como diz Balibar (Balibar, 1985b, p. 381), um princípio democrático, entendido ao mesmo tempo como tendência natural e como mecanismo regulador. Vejamos mais de perto o que é isso.

\section{Monarquia}

Toda monarquia, ou governo de um só, comporta também um aspecto aristocrático, pelo papel que os conselheiros e generais (Espinosa, 2009, VI, 5) têm nesse regime. A salvação da multidão é sempre o objetivo do regime monárquico (Ibid., VI, 8). A transferência de direitos pela multidão a um só homem, ou mesmo a alguns, se dá apenas porque, na pior das hipóteses, ela não consegue chegar à concórdia e evitar as controvérsias que degeneram em sedição.

É, além disso, certo que cada um prefere governar a ser governado. Ninguém, com efeito, concede voluntariamente o estado a outrem, conforme diz Salústio no primeiro discurso a César. ${ }^{\circ \circ}$ É, por isso, claro que uma multidão inteira nunca transferiria o seu direito para uns poucos, ou para um só, se pudesse pôr-se de acordo entre si e se das controvérsias que tão frequentemente se desencadeiam nos grandes conselhos não se passasse às revoltas. A multidão, portanto, só transfere livremente para um rei aquilo que é absolutamente impossível ela própria ter em seu poder, ou seja, o dirimir as controvérsias e o decidir de forma expedita (Ibid., p. 28).

Por isso a multidão é objeto de medo do rei (Ibid., VII, 11), notadamente, quando ela pode se armar. O rei defenderá, então, a opinião que reúna mais sufrágios, instilando assim um elemento de democracia em seu governo, e zelará para que a sua sucessão seja incontestável, de modo que o Estado permaneça estável e 
a evitar que a soberania retorne para a multidão que a detinha originalmente, mudança do um ao múltiplo que é extremamente perigosa. Isso mostra também que, mesmo na monarquia ou na teocracia, o direito pertence à multidão, que pode retomá-lo:

Podemos também deduzir isso do fato de o gládio do rei, ou direito, ser na realidade a vontade da própria multidão, ou da sua parte mais válida, ou ainda do fato de os homens dotados de razão jamais renunciarem ao seu direito a ponto do deixarem de ser homens e serem tratados como gado (Id., 2005, p. 185).

\section{Aristocracia}

O Estado aristocrático é definido como aquele cuja soberania, transmitida pela multidão, é detida por alguns, os patrícios. A diferença entre o Estado aristocrático e a democracia diz respeito a que, na aristocracia, os patrícios o são por direito inato ou por fortuna, enquanto no Estado democrático eles são escolhidos. O Estado aristocrático é mais estável que o monárquico, pois a soberania é muito forte e próxima da soberania absoluta, sem jamais chegar a isso. Em contrapartida, não há consulta à multidão (Id., 2009, VIII, 4), afastada do conselho, como das urnas. Para que esse Estado permaneça absoluto e preserve a paz e a liberdade, é preciso que a multidão goze de liberdade regrada, o que lhe assegura a constituição do Estado, como o direito de propriedade, a liberdade de culto, o direito de enriquecer e de ser candidato ao patriciado, de ter processos equânimes, sem exigir direitos particulares como os das guildas de artesãos da Alemanha (Id., 2005, p. 199).

\section{Democracia}

É o único caso no qual a soberania é absoluta, porque o possuidor e o detentor da soberania são idênticos. Forma original e frágil do Estado, ela está sempre prestes a degenerar em aristocracia, e depois em monarquia (Id., 2009, VIII, 12). É destruída 
pela adjunção perpétua de elementos novos mal integrados. Ao mesmo tempo, o grande número é a garantia de uma posição racional. A multidão não pode delirar de maneira absoluta, pois opiniões extremas anulam-se reciprocamente (Ibid., IV, 4). Trata-se de um modelo de equilíbrio de poderes (político, religioso; legislativo, executivo e judiciário) que faz de Espinosa um dos primeiros teóricos do aparelho de Estado moderno, com a ênfase no aparelho ideológico de Estado que constitui a religião.

\section{O fim da república}

Do Tratado teológico-político ao Tratado político a posição de Espinosa, que evolui a respeito da necessidade de um contrato social, permanece constante quanto ao fim da república, que é sempre a paz, conjuntamente com a liberdade e a concórdia.

Dos fundamentos do Estado, já aqui expostos, resulta com toda evidência que o seu fim último não é dominar nem subjugar os homens pelo medo e submetê-los a um direito alheio; é, pelo contrário, libertar o indivíduo do medo a fim de que ele viva, tanto quanto possível, em segurança, isto é, a fim de que mantenha da melhor maneira, sem prejuízo para si ou para os outros, o seu direito natural a existir e a agir. O fim do Estado, repito, não é fazer os homens passar de seres racionais a bestas ou autômatos: é fazer com que sua mente e o seu corpo exerçam em segurança as respectivas funções, que eles possam usar livremente a razão e que não se digladiem por ódio, cólera ou insídia, nem se manifestem intolerantes uns para com os outros. O verdadeiro fim do Estado é, portanto, a liberdade (Id., 2003, p. 302).

O meio de chegar a esse fim é notadamente a liberdade de pensar e de exprimir publicamente seu pensamento, com a condição de não levar à sedição ou à guerra civil. Liberdade, paz, concórdia e segurança sustentam-se, pois, em um círculo virtuoso. 


\section{Conclusão}

Para concluir, eu gostaria de retomar as principais teses por mim formuladas.

1. O final do século XVI é dominado em política pela corrente neoestoica que, de Justo Lípsio a Guillaume Du Vair, pensa a política tendo a guerra como horizonte, e para a qual, por isso mesmo, o problema político essencial é o da unidade de comando, retomando assim o problema de Maquiavel no capítulo XVII do Príncipe: como, a exemplo de Aníbal, que foi capaz de construir uma unidade pronta para agir a partir de uma multidão de soldados vindos de nações diferentes, produzir uma unidade de obediência e de ação a partir de indivíduos que se opõem por interesses divergentes? Nesse contexto, o melhor regime, porque o mais estável, é a monarquia, e o ideal religioso é a unidade de religião no Estado.

2. Com Hobbes, essa questão do conflito inicial, da guerra de todos contra todos, é resolvida por aquele momento primeiro de democracia (Hobbes, 1998, p. 95), em que cada um aceita transferir a totalidade de seus direitos e de sua potência para um só, em quem se concentra o poder de decisão sobre todas as coisas, inclusive em matéria religiosa. A forma privilegiada do governo é a monarquia.

3. Com Espinosa, o contrato desaparece como necessidade inaugural uma vez que o direito se confunde com a potência e há sempre entre os homens um grau mínimo de sociabilidade: cada um, sendo incapaz de satisfazer sozinho todas as suas necessidades, tem consciência de que precisa dos outros. O foco se desloca da origem para o que se visa ou para o fim do Estado que é, sem hesitação possível, a liberdade e a paz. É a perspectiva da paz e suas condições, a saber, a troca livre e generalizada de palavras, de bens e de pessoas, que faz com que todo regime estável deva ser republicano e defender a liberdade como não dominação, e não como não interferência. Daí decorre a importância das regras do direito, a assimilação da caridade à justiça, a preferência pela 
democracia e a exigência de tolerância religiosa máxima, a fim de que cada um encontre a forma de imaginário que mais e melhor lhe facilite a obediência à lei de justiça e de caridade cujo conteúdo é determinado pela lei civil e que se confunde com a busca pela paz e pela concórdia entre os cidadãos (Espinosa, 2005, III, 10).

Sed de his satis!

Referências bibliográficas

BALIBAR, E. Spinoza et la politique. Paris: PUF 1985 a. "Spinoza l'anti Orwell", Les temps modernes, n. 470, pp. 353-398, 1985b.

DIR, N. G. Penser la guerre au XVIIè siècle. Paris, 2011.

ESPINOSA, B. Traité théologico-politique [1670]. Trad. e notas Jacqueline Lagrée e P. F. Moreau. Paris: PUF, 1999. . Traité politique [1677]. Trad. e notas Charles Ramond. Paris: PUF, 2005. . Tratado político. Trad. Diogo Pires Aurélio. São Paulo: Martins Fontes, 2009. . Tratado teológico-político. Trad. Pires Aurélio. São Paulo: Martins Fontes, 2003.

HOBBES, T. On the citizen. Trad. R. Tuck e M. Silverthorne. Cambridge: Cambridge University Press, 1998.

LAGRÉE, J. Le néostoïcisme. Paris: Vrin, 2010.

LIPSE. De Constantia libri duo qui alloquium praecipue continent in publicis malis. Anvers, 1584. Trad. Lucien Du Bois. Bruxelles-Leipzig: Ed. Merzbach, 1873. Politicorum sive civilis doctrinae, libri sex qui ad principatum maxime spectant Leyde: Plantin, 1589. Trad. Charles Le Ber. Paris, 1590.

MATHERON, A. Individu et communauté chez Spinoza. Paris: Minuit, 1969, 1988.

PETTIT, P. Républicanisme. Une théorie de la liberté et du gouvernement. Paris: Gallimard, 1997. 
